Article

\title{
Energy Generation from Horse Husbandry Residues by Anaerobic Digestion, Combustion, and an Integrated Approach
}

\author{
Meike Nitsche, Frank Hensgen and Michael Wachendorf * \\ Department of Grassland Science and Renewable Plant Resources, Universität Kassel, Steinstrasse 19, \\ 37213 Witzenhausen, Germany; meike.nitsche@gmx.de (M.N.); hensgen@uni-kassel.de (F.H.) \\ * Correspondence: gnr@uni-kassel.de; Tel.: +49-561-804-1334 \\ Academic Editor: Marc Rosen \\ Received: 21 October 2016; Accepted: 17 February 2017; Published: 28 February 2017
}

\begin{abstract}
Horse-related activities often occur close to urban areas, where acreage for horse manure disposal is scarce, and subsequently alternative recovery options are necessary. Anaerobic digestion, direct combustion, and the integrated generation of solid fuel and biogas from biomass (IFBB) process are potential techniques focusing on energy provision. In this study, samples of horse faeces were analysed for chemical composition as pure feedstock and in mixture with straw or wood shavings, as well as for energy yield by biogas production or from combustion of solid fuel. It was observed that chemical properties of faeces, in a mixture with wood shavings, were promising for direct combustion, but achieved low methane yields. The methane yield of pure faeces and the straw mixture was $222.33 \pm 13.60$ and $233.01 \pm 31.32 \mathrm{l}_{\mathrm{N}} \cdot \mathrm{kg}^{-1}$ volatile solids (VS) added, respectively. The IFBB process divided the biomass into a press cake with reduced mineral concentration and a press fluid. Methane yields of press fluids were low $\left(108.2 \mathrm{l}_{\mathrm{N}} \cdot \mathrm{kg}^{-1} \mathrm{VS}_{\text {added }}\right.$, on average). The chemical composition of the press cake allowed for combustion and led to a higher gross energy potential than anaerobic digestion (two-fold higher for pure manure and the mixture with straw, and five-fold higher for the mixture with shavings). Consequently, the gross energy potential of IFBB is higher compared to anaerobic digestion, however it should be noted that local conditions might favour the implementation of anaerobic digestion.
\end{abstract}

Keywords: bioenergy; IFBB; horse faeces; stall waste; horse manure; equine waste

\section{Introduction}

As many horses are currently kept for recreation and sports, instead of for agricultural uses [1], most horse-keeping facilities are now located in urban surroundings. For example, about $75 \%$ of Swedish horse establishments are located in urban areas [2] and in Finland, 60\% of horse owners are urban inhabitants [1]. On the one hand, urban consumer's interest in horse-related activities can be advantageous for farmers located close to cities, as the equine sector opens up additional income opportunities. On the other hand, these farmers face restricted disposal possibilities for the resulting waste, as acreage for application is typically scarce [1]. This may cause considerable costs for transportation and external disposal [3].

While an average daily amount of $14 \mathrm{~kg}$ of faeces can be expected, assuming an average horse body weight $(454 \mathrm{~kg})$, the daily amount of incorporated bedding is widely dependent on stall management practices, and may account for 3.6 to $6.8 \mathrm{~kg}$ [4], although detailed data on horse stall management practises in Europe are not available. However, it can be assumed that, as a common management practice, faeces are removed daily from box stalls, while the clean bedding remains [5]. Bedding soaked with urine is removed at regular intervals (daily/monthly). About $95 \%$ of horses in Northern Germany 
are kept in box stalls [6], so nearly all of the produced stall waste is available. The overall amount of equine stall waste is unknown; although, an amount of 8 million $\mathrm{t} \cdot \mathrm{a}^{-1}$ (tons per annum/year) in Germany is possible [3]. There are several bedding materials, with straw and shavings among the most commonly used [7].

In analysing recovery options, research initially focused on composting horse manure and bedding material, since the material is conventionally used as fertiliser $[5,7,8]$. In recent years, anaerobic digestion of horse manure was well-investigated, focusing on solid-state reactors. Kusch et al. [9] achieved maximum methane yields from faeces with spent straw bedding of about $200 \mathrm{l}_{\mathrm{N}}$. (standard litres) $\cdot \mathrm{kg}^{-1}$ volatile solids (VS), testing different digestion times, inoculum shares, and reactor management strategies. Böske et al. [10] measured maximum methane yields of $235 \mathrm{l}_{\mathrm{N}} \cdot \mathrm{kg}^{-1} \mathrm{VS}$ from manure in a straw mixture, in an upflow anaerobic solid-state process. Cui et al. [11] focused on the different digestion properties of spent and clean straw bedding, with higher methane yields from spent straw. Li [12] investigated the co-digestion potential of horse manure and achieved methane yields of $299 \mathrm{l}_{\mathrm{N}} \cdot \mathrm{kg}^{-1} \mathrm{VS}$. An addition of $20 \%$ grass (based on volatile solids) led to an increase in methane yield, reaching up to $385 \mathrm{l}_{\mathrm{N}} \cdot \mathrm{kg}^{-1} \mathrm{VS}$. Mönch-Tegeder et al. [13] presented data on methane yields and digestibility, by processing horse manure and bedding materials in a liquid digestion system. Methane yields of 164-208 $1_{N} \cdot \mathrm{kg}^{-1}$ VS were achieved [13]. Böske et al. [10] reported problems with mixing and conveying horse manure due to its fibrous consistency, and Mönch-Tegeder et al. [13] observed sinking layers when woody beddings materials were utilised. These problems could be avoided by applying a mechanical pre-treatment [14] or using the material in combustion instead of digestion.

There is little information available about combustion properties of horse faeces. A study from Sweden focused on faeces in a wood shavings mixture [7], but gave no data on pure faeces. The authors concluded that the experimental results are promising, but argued that further research should focus on the possibility to reduce the $\mathrm{NO}_{x}$ emissions which result from fuel-bound nitrogen.

High mineral concentrations are generally problematic for the combustion process, as they may cause corrosion, fouling, and emissions [15]. The mineral concentration of biomass can be reduced by applying the integrated generation of solid fuel and biogas from biomass (IFBB) process. The technique was originally developed to recover semi-natural grassland energetically by a stepwise separation of the easily combustible from the easily digestible components [16]. The biomass is mashed with warm water and subsequently mechanically dehydrated, thereby producing a fibre-rich press cake and a press fluid, which contains major parts of the minerals and highly-soluble carbohydrates [17].

In this study, we consider horse manure as a feedstock for energy generation. To evaluate its technical feasibility and energy potential, we investigate (1) the chemical composition of horse faeces and beddings; (2) the effect of the IFBB process on the chemical composition of horse faeces and beddings; and the (3) the usability of horse faeces and beddings in combustion. Furthermore, we assess (4) the methane yield of horse faeces and beddings in anaerobic digestion and (5) the gross energy potential of the three recovery techniques.

\section{Materials and Methods}

\subsection{Sampling of Horse Faeces and Bedding}

Horse faeces were manually sampled from a commercial horse stable in Witzenhausen, Germany. Fifteen horses were selected for sampling, achieving a representative distribution of sex (female: eight horses, male: seven horses) and size (height $>1.48 \mathrm{~m}$ : six horses, height $<1.48 \mathrm{~m}$ : nine horses). Samples were taken on 10 consecutive days, separately for each horse, and kept at $4 \pm 1{ }^{\circ} \mathrm{C}$ prior to processing (22 days maximum). Per day and horse, the amount of sampled faeces ranged from about 1 to $15 \mathrm{~kg}$. As a result, the total amount of sampled faeces over 10 days ranged between 13 and $48 \mathrm{~kg}$, depending on the horse. Samples of single days were thoroughly mixed for each horse separately before processing. Horses were fed with roughage and oats or horse cereals, twice a day. Straw was 
taken from one batch of chopped barley straw. Shavings were taken from commercially-available shavings bedding (Goldspan; Goldenstedt, Germany), which is derived from softwood.

\subsection{Processing of Materials}

The derived faeces samples were split into three groups: five samples remained pure, five samples were mixed with straw, and five samples were mixed with shavings. Mixtures were based on fresh matter weights and were produced at a ratio of 1:5 with one part faeces and five parts straw or at a ratio of 1:9 with one part faeces and nine parts shavings. The different amounts of the bedding material were due to the specific densities of materials. Faeces with shavings have a significantly higher specific density than faeces with straw (480 versus $170 \mathrm{~kg} \cdot \mathrm{m}^{-3}$, respectively, [3]). For further analysis, three samples each of pure straw and shavings were taken.

Subsamples of each mixture and pure material were taken for chemical analysis and dry matter determination. Further subsamples of each sample were frozen at $-20 \pm 1{ }^{\circ} \mathrm{C}$ for subsequent anaerobic digestion.

\subsection{Set-Up for the Integrated Generation of Solid Fuel and Biogas from Biomass (IFBB) Process}

The remaining material was processed with the IFBB technique. First, the material was mixed with $40{ }^{\circ} \mathrm{C}$ warm water at a 1:4 ratio (material:water, on a fresh matter basis) in a modified concrete mixer heated with natural gas burners and stirred for $15 \mathrm{~min}$ at constant temperature. Subsequently, a screw press (type AV; Anhydro Ltd., Kassel, Germany), with a pitch of 1:6 and a rotation speed of 6 revolutions /min, divided the mash into a press cake and a press fluid. The cylindrical screen encapsulating the screw had a perforation of $1.5 \mathrm{~mm}$. Press fluid was immediately put into a freezer at $-20 \pm 1^{\circ} \mathrm{C}$ for storage before the digestion experiments.

\subsection{Digestion Experiments}

Digestion experiments were conducted in stirred batch experiments following the experimental setup of Zerr [18], taking the German standard into account [19]. After thawing of the substrates for $60 \mathrm{~h}$ at room temperature $\left(\sim 20^{\circ} \mathrm{C}\right), 400 \mathrm{~g}$ of raw material or $4 \mathrm{~kg}$ of press fluid, were taken for digestion in gas-proof 20 - $\mathrm{L}$ polyethylene containers at a mesophilic temperature $\left(37 \pm 1^{\circ} \mathrm{C}\right)$. Potable water $(3.6 \mathrm{~kg})$ was added to the raw material. For digestion of both the raw material and the press fluid, $8 \mathrm{~kg}$ of inoculum (digested slurry from a biogas plant, stored under mesophilic conditions) was used. Two replicates of pure inoculum were digested separately to subtract the methane yield of the inoculum from the total amount of methane produced in inoculated samples so as to calculate the actual yield from the sample. Two replicates of each raw material were digested for 35 days, while three replicates of each press fluid were digested for 14 days. Every $3 \mathrm{~h}$, the mixture was stirred for $15 \mathrm{~min}$ with a U-shaped stirrer, driven by a $12 \mathrm{~V}$ direct current motor. Biogas was collected in gas-proof bags and volume was measured with a wet drum gas meter (TG5; Ritter Apparatebau GmbH, Bochum, Germany) on digestion days 1, 2, 3, 4, 7, 9, 11, and 14 for the press fluids and, additionally, on days $16,18,21,24,28,31$, and 35 for raw materials. The daily biogas production from the press fluids and raw materials was equal to or below $3 \%$ and $1 \%$ of total biogas production at this time, respectively. Methane concentration in biogas was analysed with a gas analyser (GS IRM100; GS Messtechnik $\mathrm{GmbH}$, Ratingen, Germany). Methane yield was standardised to normalised conditions (273.15 K, $1013.25 \mathrm{hPa}$ ) and referred to as VS.

\subsection{Chemical Analysis and Calculations}

Dry matter (DM) was determined by drying of the samples at $105^{\circ} \mathrm{C}$ in a drying oven for $48 \mathrm{~h}$. Volatile solids were defined as mass loss of material during incineration in a muffle furnace at $550{ }^{\circ} \mathrm{C}$ after drying at $105{ }^{\circ} \mathrm{C}$ in a drying oven. Press cake was dried at $65^{\circ} \mathrm{C}$ for elemental analysis and a subsample was taken for determination of DM. Samples for fibre (raw material) and elemental analysis (raw material and press cake) were ground with a cutting mill (SM 1; Retsch GmbH, Haan, 
Germany) to pass a $5 \mathrm{~mm}$ sieve and, subsequently, with a sample mill (1093 Cyclotec; Foss GmbH, Hamburg, Germany) to $1 \mathrm{~mm}$.

Ash concentration was measured by incineration of a dried $\left(\right.$ at $\left.105^{\circ} \mathrm{C}\right)$ subsample at $550{ }^{\circ} \mathrm{C}$ in a muffle furnace. One sample of pure faeces with an ash content of $40.36 \% \mathrm{DM}$ was excluded from further analysis because the high ash content was due to sand contamination since the horse was kept on sand instead of straw or shavings. X-ray fluorescence analysis was conducted to determine concentrations of $\mathrm{Cl}, \mathrm{K}, \mathrm{Ca}, \mathrm{P}, \mathrm{S}$, and $\mathrm{Mg}$ in straw and horse faeces mixtures. For determination of $\mathrm{Cl}, \mathrm{K}$, $\mathrm{Ca}, \mathrm{P}, \mathrm{S}$, and $\mathrm{Mg}$ concentrations in shavings, inductively coupled plasma optical emission spectrometry was applied. $\mathrm{C}, \mathrm{H}$ and $\mathrm{N}$ concentrations were determined with an elemental analyser (Vario Max $\mathrm{CHN}$; Elementar Analysesysteme $\mathrm{GmbH}$, Hanau, Germany) using $150 \mathrm{mg}$ of dried material. Relative reduction (RR) of elements, DM and lower heating value by the IFBB process were calculated as:

$$
\mathrm{RR}=\frac{\text { Concentration of } \mathrm{x} \text { in raw material }- \text { Concentration of } x \text { in press cake }}{\text { Concentration of } x \text { in raw material }}
$$

where $x$ is the measured element.

From $\mathrm{C}, \mathrm{H}$, and $\mathrm{N}$ concentrations, the higher heating value (HHV) was calculated as [20]:

$$
\mathrm{HHV}\left[\frac{\mathrm{MJ}}{\mathrm{kg} \mathrm{DM}}\right]=\frac{3.55 C^{2}-232 \mathrm{C}-2230 H+51.2 \mathrm{C} * H+131 N+20,600}{1000}
$$

Lower heating value (LHV) was calculated from the higher heating value (HHV) using the formula:

$$
\operatorname{LHV}\left[\frac{\mathrm{MJ}}{\mathrm{kg} \mathrm{DM}}\right]=\mathrm{HHV}-\left(8.937 * \frac{H \% \mathrm{DM}}{100}\right) * 2.2
$$

where 8.937 is the mass share of hydrogen in a water molecule and 2.2 is the enthalpy of water vaporisation.

A fibre analyser (ANKOM A220; Ankom Technology, Macedon, NY, USA) was utilised to measure the concentration of fibres: neutral detergent fibre (NDF), acid detergent fibre (ADF), and acid detergent lignin (ADL). Subsamples of about $0.5 \mathrm{~g}$ were sealed in a filter bag and boiled with neutral detergent solution and alpha-amylase, for NDF determination. We chose not to use $\mathrm{Na}_{2} \mathrm{SO}_{3}$ because it regularly leads to an underestimation of NDF, due to the loss of lignin [21]. For ADF determination, filter bags were boiled with acid detergent solution and water and subsequently rinsed with acetone. ADL analysis was conducted by adding $\mathrm{H}_{2} \mathrm{SO}_{4}$ solution, subsequently washing with water, and adding $\mathrm{NaOH}$ solution. Filter bags were then washed with hot water and rinsed with acetone. Filter bags were incinerated in a muffle furnace at $550{ }^{\circ} \mathrm{C}$ and $\mathrm{NDF}, \mathrm{ADF}$, and $\mathrm{ADL}$ concentrations were calculated as:

$$
\text { Fibre type }[\% \text { of DM }]=\frac{\left(m_{3}-\left(m_{1} * C\right)\right) * 100}{m_{2} * \mathrm{DM}}
$$

where $m_{1}$ is the mass of the empty filter bag, $m_{2}$ is the mass of the sample, $m_{3}$ is the mass of organic matter after boiling and incineration and $C$ is the "blank-bag correction" factor, which indicates the mass change of the filter bag during processing.

\subsection{Statistical Analysis}

Statistical parameters and figures were generated by utilizing R software (Version 3.0.2., R Foundation for statistical computing, Vienna, Austria) [22]. To determine significant differences, either the Wilcoxon or Kruskal-Wallis test was conducted, depending on the number of groups (two or more than two, respectively). Both tests are nonparametric and developed for independent groups [23]. In the case of the Kruskal-Wallis test, we applied the post-hoc function "kruscalmc" [24]. 


\section{Results}

\subsection{Chemical Properties of Raw Material}

DM content, as well as C concentration and LHV, were highest in faeces mixed with shavings compared to pure faeces and the mixture with straw (Table 1). For C and LHV, the difference between the shavings and straw mixtures was significant $(p<0.05)$. The shavings mixture resulted in a LHV of 17.51 MJ $\cdot \mathrm{kg}^{-1}$, which is about $1 \mathrm{MJ} \cdot \mathrm{kg}^{-1}$ higher than the LHV of faeces in mixture with straw.

In contrast, concentrations of $\mathrm{H}, \mathrm{Cl}$, and $\mathrm{K}$, as well as ash content were highest in the mixture with straw and significantly lower in the mixture with shavings. The difference was particularly pronounced for $\mathrm{Cl}$, with a three-fold higher concentration in the mixture with straw $(0.22 \% \mathrm{DM})$ than in mixture with shavings $(0.07 \% \mathrm{DM})$. Values for $\mathrm{H}, \mathrm{Cl}, \mathrm{K}$, and ash of pure faeces ranged between the values for the mixtures.

Table 1. Chemical properties of horse faeces, straw and shavings, as well as mixtures, with standard deviations. Data of coniferous wood without bark are given for comparison.

\begin{tabular}{ccccccc}
\hline Chemicals & Straw & Shavings & Horse Faeces & $\begin{array}{c}\text { Horse Faeces } \\
\text { with Straw }\end{array}$ & $\begin{array}{c}\text { Horse Faeces } \\
\text { with Shavings }\end{array}$ & $\begin{array}{c}\text { Coniferous } \\
\text { Wood without } \\
\text { Bark }\end{array}$ \\
\hline DM & - & - & $19.88 \pm 1.31^{\mathrm{a}}$ & $28.36 \pm 1.28^{\mathrm{a}, \mathrm{b}}$ & $31.92 \pm 2.10^{\mathrm{b}}$ & - \\
C & $45.11 \pm 0.20$ & $49.77 \pm 0.03$ & $46.01 \pm 0.42^{\mathrm{a}, \mathrm{b}}$ & $44.36 \pm 1.13^{\mathrm{a}}$ & $47.15 \pm 0.97^{\mathrm{b}}$ & 51 \\
H & $5.40 \pm 0.03$ & $5.71 \pm 0.02$ & $5.43 \pm 0.04^{\mathrm{a}, \mathrm{b}}$ & $5.63 \pm 0.12^{\mathrm{a}}$ & $5.47 \pm 0.13^{\mathrm{b}}$ & 6.3 \\
Cl & $0.32 \pm 0.00$ & $<0.003$ & $0.10 \pm 0.05^{\mathrm{a}, \mathrm{b}}$ & $0.22 \pm 0.05^{\mathrm{a}}$ & $0.07 \pm 0.02^{\mathrm{b}}$ & 0.01 \\
K & $1.26 \pm 0.01$ & $0.04 \pm 0.00$ & $1.40 \pm 0.22^{\mathrm{a}, \mathrm{b}}$ & $1.64 \pm 0.17^{\mathrm{a}}$ & $0.96 \pm 0.13^{\mathrm{b}}$ & 0.04 \\
N & $0.51 \pm 0.01$ & $0.02 \pm 0.00$ & $1.24 \pm 0.11^{\mathrm{a}}$ & $1.07 \pm 0.11^{\mathrm{a}, \mathrm{b}}$ & $0.70 \pm 0.07^{\mathrm{b}}$ & 0.10 \\
Ca & $0.37 \pm 0.03$ & $0.08 \pm 0.00$ & $0.47 \pm 0.06^{\mathrm{a}}$ & $0.40 \pm 0.03^{\mathrm{a}, \mathrm{b}}$ & $0.29 \pm 0.06^{\mathrm{b}}$ & 0.09 \\
Mg & $0.09 \pm 0.00$ & $0.01 \pm 0.00$ & $0.30 \pm 0.07^{\mathrm{a}}$ & $0.26 \pm 0.03^{\mathrm{a}}$ & $0.21 \pm 0.05^{\mathrm{a}}$ & 0.015 \\
P & $0.09 \pm 0.00$ & $35.7 \pm 1.20^{2}$ & $0.52 \pm 0.10^{\mathrm{a}}$ & $0.39 \pm 0.06^{\mathrm{a}, \mathrm{b}}$ & $0.34 \pm 0.09^{\mathrm{b}}$ & 0.006 \\
S & $0.08 \pm 0.00$ & $<0.004$ & $0.16 \pm 0.01^{\mathrm{a}}$ & $0.15 \pm 0.01^{\mathrm{a}, \mathrm{b}}$ & $0.09 \pm 0.02^{\mathrm{b}}$ & 0.02 \\
Ash & $7.54 \pm 0.70$ & - & $11.75 \pm 0.62^{\mathrm{a}}$ & $12.93 \pm 2.12^{\mathrm{a}}$ & $7.86 \pm 1.65^{\mathrm{b}}$ & 0.30 \\
LHV & $16.79 \pm 0.08$ & $16.73 \pm 0.01$ & $17.17 \pm 0.15^{\mathrm{a}, \mathrm{b}}$ & $16.62 \pm 0.34^{\mathrm{a}}$ & $17.51 \pm 0.34^{\mathrm{b}}$ & 19.18 \\
NDF & $78.50 \pm 5.30$ & $86.88 \pm 2.25$ & $66.09 \pm 2.14^{\mathrm{a}}$ & $68.26 \pm 4.06^{\mathrm{a}}$ & $76.68 \pm 4.13^{\mathrm{b}}$ & - \\
ADF & $55.78 \pm 12.13$ & $74.82 \pm 0.63$ & $42.30 \pm 0.48^{\mathrm{a}}$ & $46.22 \pm 6.45^{\mathrm{a}}$ & $62.64 \pm 5.69^{\mathrm{b}}$ & - \\
ADL & $13.07 \pm 8.08$ & $25.97 \pm 0.31$ & $8.83 \pm 0.36^{\mathrm{a}, \mathrm{b}}$ & $8.29 \pm 0.50^{\mathrm{a}}$ & $16.85 \pm 1.63^{\mathrm{b}}$ & - \\
\hline
\end{tabular}

Different letters $\left({ }^{\mathrm{a} / \mathrm{b}}\right)$ indicate significant differences among horse faeces and mixtures. Dry matter (DM) content is given in \% FM. Element, ash, and fibre concentrations are given in \% DM. Lower heating value (LHV) is given in $\mathrm{MJ} \cdot \mathrm{kg}^{-1} \mathrm{DM}$. ADF, acid detergent fibre; ADL, acid detergent lignin; DM, dry matter; LHV, lower heating value; $\mathrm{NDF}$, neutral detergent fibre ${ }^{1}[15]$, partly calculated based on data given ${ }^{2} \mathrm{mg} \cdot \mathrm{kg}^{-1} \mathrm{DM}$.

Regarding the concentration of $\mathrm{N}, \mathrm{Ca}, \mathrm{Mg}, \mathrm{P}$, and $\mathrm{S}$, much higher values were detected in pure faeces compared to the mixture with shavings. Concentrations of $\mathrm{Ca}, \mathrm{Mg}$, and $\mathrm{S}$ in pure faeces were regularly about one and a half times the concentration in the mixture with shavings, and pure faeces had more than fifty-fold the concentration of $\mathrm{P}$ and $\mathrm{N}$ as in pure shavings.

Fibre concentrations were highest in the shavings and consequently, the mixture of faeces and shavings had significantly higher neutral detergent fibre (NDF, 76.68\% DM), acid detergent fibre (ADF, $62.64 \% \mathrm{DM})$ concentrations than pure faeces $(66.09 \%$ and $42.30 \% \mathrm{DM}$, respectively), and the mixture of faeces and straw (68.26\% and 46.22\% DM, respectively). Acid detergent lignin (ADL) differed between mixtures, with pure faeces ranging in between.

\subsection{Influence of IFBB Process on Chemical Properties}

The IFBB process reduced most mineral concentrations significantly, except for Ca in horse faeces, which was reduced, although not significantly (Table 2). Furthermore, concentrations of C, H, and DM content were elevated. For DM content in horse faeces, the increase was particularly strong, with a relative change of $105 \%$. High reductions were detected for $\mathrm{Cl}$ and $\mathrm{K}$, with a more than $80 \%$ difference detected regularly. Lowest reduction rates were found for Ca (about 30\%) and N (39\%-53\%). Relative reduction of $\mathrm{Mg}$ and $\mathrm{S}$ was about $50 \%$. Ash content was reduced in pure faeces and mixtures, 
though not significantly in the mixture of faeces and straw. LHV was elevated in all materials, but only significantly in the mixture of faeces and shavings.

Table 2. Relative reduction (in \%) of concentrations achieved by the integrated generation of solid fuel and biogas from biomass (IFBB) process.

\begin{tabular}{cccc}
\hline & Horse Faeces & Horse Faeces with Straw & Horse Faeces with Shavings \\
\hline $\mathrm{DM}$ & $-105.00^{*}$ & $-47.33^{* *}$ & $-46.38^{*}$ \\
$\mathrm{C}$ & $-1.68^{\mathrm{ns}}$ & $-2.19^{\mathrm{ns}}$ & $-2.57^{*}$ \\
$\mathrm{H}$ & $-1.57^{\mathrm{ns}}$ & $-3.46^{*}$ & $-2.85^{*}$ \\
$\mathrm{Cl}$ & $89.12^{* *}$ & $91.67^{*}$ & $90.27^{*}$ \\
$\mathrm{~K}$ & $82.32^{*}$ & $79.72^{* *}$ & $77.77^{* *}$ \\
$\mathrm{~N}$ & $48.99^{*}$ & $38.62^{* *}$ & $52.72^{*}$ \\
$\mathrm{Ca}$ & $32.94^{\mathrm{ns}}$ & $34.40^{* *}$ & $35.23^{*}$ \\
$\mathrm{P}$ & $70.92^{*}$ & $71.42^{* *}$ & $74.81^{*}$ \\
$\mathrm{~S}$ & $47.20^{*}$ & $55.79^{*}$ & $58.14^{*}$ \\
$\mathrm{Mg}$ & $51.05^{*}$ & $51.81^{* *}$ & $51.94^{*}$ \\
$\mathrm{Ash}$ & $32.75^{*}$ & $23.43^{\mathrm{ns}}$ & $38.29^{*}$ \\
$\mathrm{LHV}$ & $-1.19^{\mathrm{ns}}$ & $-1.52^{\mathrm{ns}}$ & $-2.26^{*}$ \\
\hline
\end{tabular}

DM, dry matter; Asterisks indicate significant differences between raw material and press cake after processing; ${ }^{*} p<0.05 ;{ }^{* *} p<0.01$; ns not significant.

\subsection{Chemical Properties of Press Cake}

In the press cake, concentrations of $\mathrm{Cl}, \mathrm{K}$, and $\mathrm{N}$ were highest in horse faeces with straw $(0.018 \%$, $0.33 \%$, and $0.66 \% \mathrm{DM}$, respectively; Figure 1 ). Values for horse faeces with shavings were substantially lower $(0.007 \%, 0.214 \%$, and $0.33 \% \mathrm{DM}$, respectively). $\mathrm{Ca}, \mathrm{P}, \mathrm{Mg}$, and $\mathrm{S}$ concentrations in the press cake were highest in pure horse faeces, though the difference in $\mathrm{P}$ among materials was not significant. For $\mathrm{Ca}, \mathrm{Mg}$, and $\mathrm{S}$, the difference in concentrations between pure faeces and the mixture of faeces and shavings was significant.
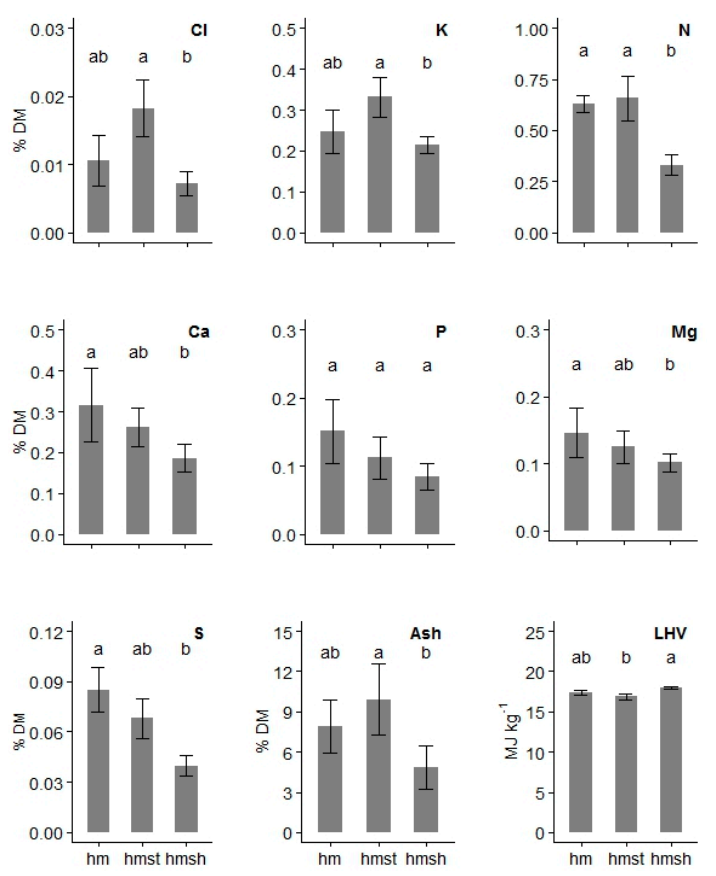

Figure 1. Chemical properties of press cake. Different letters indicate significant differences among materials; hm, horse manure (faeces); hmst, horse manure (faeces) with straw; hmsh, horse manure (faeces) with shavings; LHV, lower heating value. 
Ash content of horse faeces with straw $(9.90 \% \mathrm{DM})$ was about twice as high as horse faeces with shavings $(4.85 \% \mathrm{DM})$, while ash content of pure faeces $(7.90 \% \mathrm{DM})$ was in between these values. This is consistent with the LHV of press cakes, which was significantly higher in horse faeces with shavings $\left(17.9 \mathrm{MJ} \cdot \mathrm{kg}^{-1} \mathrm{DM}\right)$ than in horse faeces with straw $\left(16.87 \mathrm{MJ} \cdot \mathrm{kg}^{-1} \mathrm{DM}\right)$. LHV of press cake from pure faeces was $17.37 \mathrm{MJ} \cdot \mathrm{kg}^{-1} \mathrm{DM}$.

\subsection{Methane Yield from Anerobic Digestion of Raw Materials and Press Fluids}

Digestion of horse faeces and horse faeces mixed with straw resulted in mean methane yields of $222.33 \pm 13.60$ and $233.01 \pm 31.32 \mathrm{lN} \cdot \mathrm{kg}^{-1} \mathrm{VS}$, respectively (Figure 2). In contrast, digestion of faeces in a shavings mixture yielded only about half as much methane $\left(97.13 \pm 15.45 \mathrm{lN} \cdot \mathrm{kg}^{-1} \mathrm{VS}\right)$. Methane yield from digestion of press fluids was considerably lower than from the digestion of raw materials. Digestion of press fluid from faeces, faeces with straw, and faeces with shavings resulted in yields of $104.01 \pm 18.08 \mathrm{lN} \cdot \mathrm{kg}^{-1} \mathrm{VS}, 118.10 \pm 13.00 \mathrm{lN} \cdot \mathrm{kg}^{-1} \mathrm{VS}$, and $102.49 \pm 11.43 \mathrm{lN} \cdot \mathrm{kg}^{-1} \mathrm{VS}$, respectively.

Concentrations of volatile solids were $87.55 \%, 87.46 \%$, and $90.6 \%$ DM in faeces, faeces in mixture with straw and faeces in mixture with shavings, respectively. In the press fluid, the concentration of volatile solids was reduced to $73.85 \%, 69.25 \%$ and $70.36 \%$ DM in faeces, faeces in mixture with straw, and faeces in mixture with shavings, respectively.

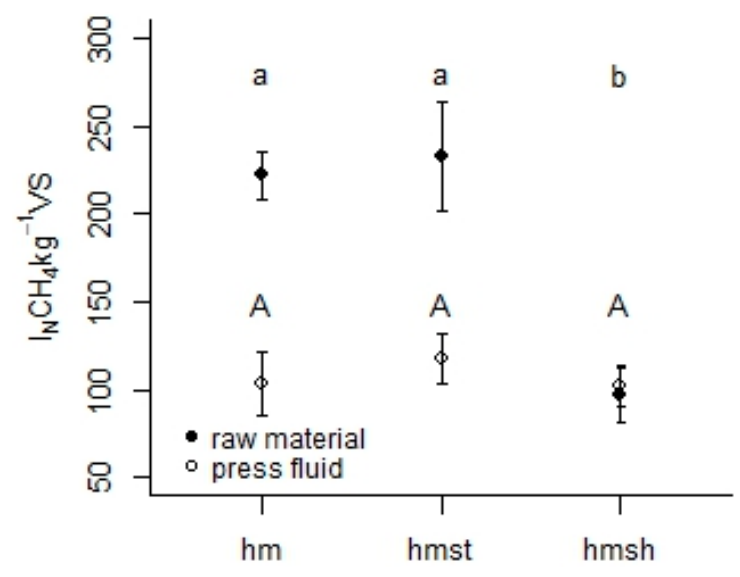

Figure 2. Methane yields from anaerobic digestion of horse faeces and mixtures, with standard deviations. Different lower letters indicate significant differences between raw materials. Different capital letters indicate significant differences between press fluids; hm, horse manure (faeces); hmst, horse manure (faeces) with straw; hmsh, horse manure (faeces) with shavings.

\subsection{Gross Energy Yields}

Anaerobic digestion of horse faeces lead to a gross energy potential of $7.0 \mathrm{GJ} \cdot \mathrm{a}^{-1} \cdot$ horse $^{-1}$ (Table 3 ) corresponding to an energy content of $35 \mathrm{MJ} \cdot \mathrm{m}^{-3}$ methane. Gross energy output from anaerobic digestion of mixtures was higher than that of pure faeces, with $22.0 \mathrm{GJ} \cdot \mathrm{a}^{-1} \cdot$ horse $^{-1}$ for the mixture with straw and $10.8 \mathrm{GJ} \cdot \mathrm{a}^{-1}$.horse ${ }^{-1}$ for the mixture with shavings. Direct combustion resulted in an increased gross energy potential. IFBB processing of materials followed by combustion of the press cake and digestion of press fluid produced a somewhat lower energy output than direct combustion of materials, but still increased the energy output compared to anaerobic digestion. This energy output increase from the IFBB process was twofold, fivefold and six-fold for pure faeces, the shavings mixture, and the straw mixture, respectively compared to anaerobic digestion of the raw materials. Considering a quantity of 500 million horses in the EU 27 [3], the gross energy potential of horse faeces ranges from 35 to $85 \mathrm{PJ} \cdot \mathrm{a}^{-1}$. By adding bedding material, the potential reaches $308 \mathrm{PJ} \cdot \mathrm{a}^{-1}$. 
Table 3. Comparison of gross energy output between techniques.

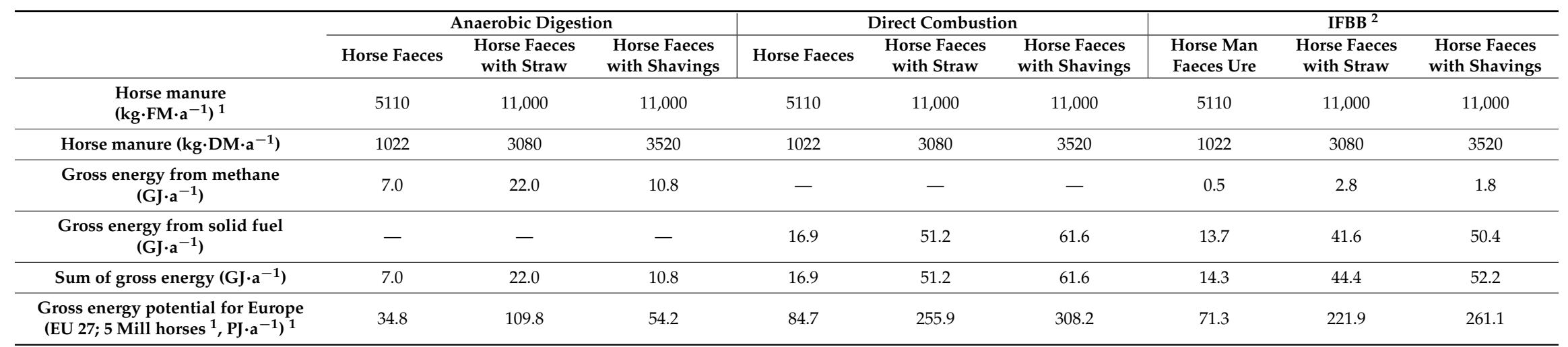

Numbers refer to one horse unless otherwise stated. ${ }^{1}$ calculated with data of $[3,4] ;{ }^{2}$ The calculation is based on the assumption that $20 \%$ of DM is transferred into the press fluid and $80 \%$ of DM into the press cake. Heating values of solid fuels are based on the results presented above. 


\section{Discussion}

\subsection{Suitability of Raw Materials and Press Cakes for Combustion}

In comparison to coniferous wood [15] taken as common solid fuel, concentrations of minerals in faeces and its mixtures were substantially higher. For combustion, elevated $\mathrm{S}$ and $\mathrm{N}$ concentrations in faeces and in faeces mixed with straw might be problematic due to potential $\mathrm{NO}_{\mathrm{x}}$ and $\mathrm{SO}_{\mathrm{x}}$ emissions, as well as the corrosive effects in the case of $S$ [15]. Obernberger et al. [15] suggested guiding values for the concentrations of $\mathrm{N}$ and $\mathrm{S}$ in solid biofuels which shall not be exceeded, namely $0.1 \%$ DM for $\mathrm{S}$ and $0.6 \%$ DM for N. N concentrations in faeces and mixtures were well above this value, though only slightly in the case of the mixture with shavings. Regarding $S$ concentrations, values for pure faeces and the mixture with straw exceeded the guiding value, whereas the concentration of $S$ in the mixture with shavings is classified as unproblematic.

A guiding value is also given for $\mathrm{Cl}(<0.1 \% \mathrm{DM},[15])$, which is due to the risk of corrosion and detrimental emissions. Faeces in mixture with straw exceeded this value; however, pure faeces and faeces with shavings were in accordance. Herbaceous material regularly contains considerable amounts of $\mathrm{Cl}$. Hensgen et al. [25], for instance, measured $\mathrm{Cl}$ concentrations of about $0.4 \% \mathrm{DM}$ in semi-natural grassland and Aho et al. [26] report $\mathrm{Cl}$ concentrations of about $0.5 \% \mathrm{DM}$ in both wheat straw and corn stover.

Lundgren and Pettersson [7] reported higher values for N, S, and $\mathrm{Cl}$ concentrations (about $0.85 \%$, $0.13 \%, 0.24 \% \mathrm{DM}$, respectively, calculated from given data) in a mixture of horse faeces and shavings, although they assumed a higher share of shavings in the mixture. Whether this disparity results from a quality difference between the shavings or faeces cannot be determined, as data on the pure materials were not given. Yet, $\mathrm{Li}$ [12] also found higher $\mathrm{N}$ and S concentrations (2.4\% and 0.67\% DM, respectively) in pure faeces than in our study. A further explanation for the deviation of results may be that urine was not included in our study since we used clean bedding. In contrast, Lundgren and Pettersson [7] used bedding from stall boxes, which is at least partly soaked with urine. Additionally, Böske et al. [10] showed that the type of fodder may influence the $\mathrm{N}$ concentration in horse manure (fed with hay: $1.36 \% \mathrm{DM}$, fed with silage: $0.96 \% \mathrm{DM}$ ), which makes a direct comparison of literature findings difficult.

It should be noted that high concentrations of $\mathrm{K}$ may lead to corrosion and a reduced ash melting point during combustion [15,27]. Therefore, low concentrations are favourable. However, $\mathrm{K}$ concentration in horse faeces was high in comparison to the other investigated materials. Li [12] detected lower $\mathrm{K}$ concentrations in pure faeces $(0.9 \% \mathrm{DM})$ than in our study. Deviations in mineral concentration in faeces might be caused by different feeding strategies; however, no details are given by Li [12] regarding horse feed, so this cannot be verified.

Although ash content was high in both the faeces and mixtures (7.86\%-11.75\% DM), which reduces the heating value of the solid fuel, the value for faeces with shavings is in accordance with the German standard for biofuels derived from herbaceous material (class B, $\leq 10 \%$ DM, [28]. Lundgren and Pettersson [7] found ash contents of 5\%-7\% DM in a mixture of faeces and shavings, composed of $40 \%-80 \%$ shavings on a DM basis. In comparison, we assumed a shavings share (in DM) of approximately $30 \%$. Faeces mixed with shavings is not very problematic for combustion. The low mineral concentrations and the low ash content of wood shavings lead to tolerable values for $N, S$, and $\mathrm{Cl}$. However, in pure faeces, $\mathrm{N}$ and $\mathrm{S}$ concentrations are alarming regarding the combustion process, while in faeces mixed with straw, N, S, and $\mathrm{Cl}$ concentrations exceed the mentioned guiding values for combustion. Therefore, a reduction of these elements prior to combustion seems favourable.

The IFBB process reduced N, S and $\mathrm{Cl}$ concentrations in biomass significantly and in a similar magnitude to former studies on different biomass types. By treating grass from roadside verges with the IFBB process, Piepenschneider et al. [29] detected relative reduction rates for $\mathrm{Cl}(90 \%)$ and $\mathrm{K}(82 \%)$ which are in accordance with our study. However, their N concentration was only reduced by $29 \%$, which is substantially below the reduction rate we could achieve with horse faeces and mixtures. 
This might indicate that $\mathrm{N}$ compounds in faeces are of higher water solubility than in herbaceous material. Reduction of ash content was in the range of the reduction detected for grass from roadside verges $(35 \%,[29])$.

This reduction resulted in a LHV of the press cake from faeces with shavings which is only about $1 \mathrm{MJ} \cdot \mathrm{kg}^{-1} \mathrm{DM}$ less than that of coniferous wood and identical with the LHV found in press cake from semi-natural grassland (17.9 MJ $\cdot \mathrm{kg}^{-1} \mathrm{DM}$, [30]). Lundgren and Pettersson [7] found a LHV of 18.14 MJ $\cdot \mathrm{kg}^{-1} \mathrm{DM}$ in a mixture of faeces and shavings without pretreatment. However, the mixture contained higher shares of shavings ( $40-80 \% \mathrm{DM}$ ) than the mixture used in our experiment (about $30 \%$ shavings on a DM basis).

Additionally, $\mathrm{S}$ concentration in the press cake from pure faeces and the mixture of faeces and straw $(0.085 \%$ and $0.068 \% \mathrm{DM}$, respectively) fell below the guiding value for an unproblematic combustion [15]. In contrast, $\mathrm{N}$ concentrations in these materials were still too high, though only slightly. Advanced combustion techniques, e.g., air staging or secondary measures [15], are able to cope with an N concentration in this range. Lundgren and Pettersson [7] conducted combustion experiments with a mixture of faeces and shavings without pre-treatment using a boiler adapted to biomass. They reported NOx emissions below $400 \mathrm{mg} \cdot \mathrm{Nm}^{-3}$, which is below the German emission limiting value (500 $\mathrm{mg} \cdot \mathrm{Nm}^{-3}$ in combustion plants $<10 \mathrm{MW}$, [31]). Considerable reduction of $\mathrm{Cl}$ and $\mathrm{K}$ concentrations through the IFBB process leads to the conclusion that no harmful influence is expected from these elements. The $\mathrm{Cl}$ concentration in press cakes from the mixture of faeces with shavings $(0.007 \% \mathrm{DM})$ was even in the range of coniferous wood. Furthermore, the IFBB process simultaneously increased the DM content in the resulting press cake, which is of particular importance, as drying of solid fuel prior to combustion is necessary and might require additional energy input if accomplished with thermal energy $[2,30]$.

\subsection{Suitability of Raw Materials and Press Fluids for Anaerobic Digestion}

The lower digestibility of faeces in mixture with shavings is in accordance with the higher concentration of lignin in this material compared to pure faeces or to faeces in mixture with straw. While the NDF concentration of pure faeces was similar to the findings of Li [12], the measured ADL concentration was substantially lower in our study (9\% DM vs. $15 \%$ DM [12]). However, methane yields observed by Li [12] were about $75 \mathrm{l}_{\mathrm{N}} \cdot \mathrm{kg}^{-1} \mathrm{VS}$ higher than ours. Another study confirms ADL concentrations in pure faeces in the range of $8 \%-12 \%$ DM [13]. Mönch-Tegeder et al. [13] presented NDF concentrations of straw bedding in the range of $70 \%-80 \%$ DM and ADL concentrations of $7 \%-10 \%$ $\mathrm{DM}$, which is in accordance with our findings. Specific methane yield from unused pure straw bedding was about $207 \mathrm{l}_{\mathrm{N}} \cdot \mathrm{kg}^{-1} \mathrm{VS}$ [13]. Yet, the authors urge that the actual yield in practice is dependent on straw quality which, in turn, depends on time of harvest and weather conditions [13].

Böske et al. [10] reported methane yields of $235.4 \mathrm{l}_{\mathrm{N}} \cdot \mathrm{kg}^{-1} \mathrm{VS}$ from digestion of horse manure (from horses fed with hay) in mixture with straw, which is nearly identical with our results. With $78.1 \mathrm{l}_{\mathrm{N}} \cdot \mathrm{kg}^{-1}$ VS, the methane yields from digestion of horse faeces with wood shavings were close to the methane yields in the present study. In accordance with our study, Böske et al. [10] also used clean bedding material for their experiments. Digestion of spent wheat straw resulted in higher methane yields than digestion of clean straw, but total yield was only about $150 \mathrm{l}_{\mathrm{N}} \cdot \mathrm{kg}^{-1} \mathrm{VS}$ [11]. The authors hypothesised that the aerobic degradation of organic compounds by fungal and bacterial microorganisms may facilitate the anaerobic digestion. In contrast, aeration did not enhance the methane yield in an experiment with a mixture of horse faeces and spent straw (without aeration: max. $192 \mathrm{l}_{\mathrm{N}} \cdot \mathrm{kg}^{-1} \mathrm{VS}$, with aeration: $140 \mathrm{l}_{\mathrm{N}} \cdot \mathrm{kg}^{-1}$ VS) [9]. Equine urine contains about $7 \%$ organic matter [32], which might be available for digestion. Therefore, anaerobic digestion of manure and mixtures may account for higher yields than reported in this study. Mönch-Tegeder et al. [13] concluded that straw-based manure is a suitable input material for anaerobic digestion.

Methane yields from anaerobic digestion of press fluids in this study were lower than known values for digestion of press fluids from semi-natural grassland (up to $450 \mathrm{l}_{\mathrm{N}} \cdot \mathrm{kg}^{-1} \mathrm{VS}$ [33]). 
The considerable deviation of digestion yields from press fluids versus raw materials suggests two possible explanations: On the one hand, volatile solids of press fluids might be less digestible than those contained in raw materials. This would imply that during mechanical dehydration, the digestible compounds are, at least partly, absorbed in the press cake. On the other hand, the digestion process might be hampered by substances that are washed into the press fluid. It is fairly well-established that ammonia produced from the degradation of nitrogenous material can inhibit anaerobic digestion, with the $\mathrm{C} / \mathrm{N}$ ratio of the substrate assumed as an indicator $[12,34]$. The $\mathrm{C} / \mathrm{N}$ ratio of horse faeces was found to be well below the value for grasses (18.32 and 40.27, respectively [12]). As the majority of fibres remains in the press cake, it seems likely that the $\mathrm{C} / \mathrm{N}$ ratio in the press fluid is lower than in the raw material. However, the $\mathrm{pH}$ value of digestate from the press fluid of pure faeces was 7.6 on average and, thus, did not indicate an inhibition by ammonium. Horse manure was found to lack trace elements (e.g., $\mathrm{Ni}, \mathrm{Fe}, \mathrm{Co}[13])$. If the few trace elements are primarily contained in the press cake, the digestion process of the press fluid might be inhibited. However, Piepenschneider et al. [29] showed a considerable mass flow of trace elements into the press fluid when treating grass with the IFBB technique. Additionally, the inoculum provides trace elements. Horse manure is also rich in organic acids [12], which are highly digestible. They might be transferred into the press fluid primarily and might have imbalanced the digestion process due to fast acetogenesis.

\subsection{Energy Potential}

The energy potential of direct combustion exceeded the potential of anaerobic digestion. Baky [2] calculated a net energy potential of $9005 \mathrm{MJ} \cdot \mathrm{t}^{-1}$ faeces with a DM content of $23.3 \%$ recovered by combustion, which is about half of our gross energy. The primary energy input to output ratio in digestion scenarios is approximately $10.5 \%$ for straw and $64.0 \%$ for cattle manure [35]. Taking the mean of these two values (37\%) as an energy input to assess the net energy output from digestion of horse faeces, direct combustion still provides higher energy yields. However, the energy potential does not reflect the technical suitability of the fuel, as mineral concentrations might restrict the usability of pure faeces and the straw mixtures for combustion. These limitations do not apply for mixtures with larger amounts of shavings. Therefore, direct combustion of such mixtures seems favourable.

The technical problems of utilising pure faeces and faeces with straw may be overcome with pre-processing techniques, like the IFBB process, which shows an enhanced gross energy potential in comparison to anaerobic digestion. The IFBB process will have an estimated energy self-consumption of $50 \%$ of the substrate's energy content ([30], calculated for semi-natural grassland). Assuming the above calculated input to output ratio of $37 \%$ for faeces in anaerobic digestion, the difference between techniques diminishes. Whether the IFBB technique provides better energy balances in practice will depend on local conditions, taking available infrastructure, type of bedding material, and quantity of faeces into account.

\section{Conclusions}

Horse manure poses frequent management difficulties. However, it also has great potential to be used as an energy source. Faeces mixed with shavings seems directly suitable for combustion, whereas pure faeces and faeces mixed with straw pose a risk for the combustion unit without pre-processing, due to high concentrations of $\mathrm{S}, \mathrm{K}, \mathrm{Cl}$, and $\mathrm{N}$. The IFBB treatment reduces mineral concentrations and increases lower heating values. Anaerobic digestion of faeces and mixtures is possible; however, depending on the actual composition of the stall waste, the IFBB process can be preferable due to a potentially better net energy balance. This applies, in particular, to faeces mixed with wood shavings.

Acknowledgments: We received funds by the Deutsche Forschunsgemeinschaft (DFG) for covering the costs to publish in open access.

Author Contributions: Meike Nitsche, Frank Hensgen and Michael Wachendorf conceived and designed the experiments; Frank Hensgen performed the experiments; Meike Nitsche analysed the data; Meike Nitsche, Frank Hensgen and Michael Wachendorf wrote the paper. 
Conflicts of Interest: The authors declare no conflict of interest.

\section{References}

1. Häggblom, M.; Rantamäki-Lathinen, L.; Vihinen, H. Equine Sector Comparison between The Netherlands, Sweden and Finland: LIFE04 ENV/FI/000299; Equine Life: Helsinki, Finland, 2008.

2. Baky, A. Life Cycle Inventory \& Assessment Report: Combustion of Horse Manure with Heat Utilisation, Sweden: Baltic Forum for Innovative Technologies for Sustainable Manure Management; Knowledge Report; Swedish Institute of Agricultural and Environmental Engineering: Uppsala, Sweden, 2013.

3. Kusch, S. Horse Stall Waste: Amounts, Management, Bioenergy Generation. Electron. Int. Interdiscip. Conf. 2013, 2, 423-428.

4. Wheeler, E.; Zajaczkowski, J.S. Horse Stable Management. Pennsylvania State University, 2009. Available online: http:/ / extension.psu.edu/animals/equine/horse-facilities/horse-stable-manure-management/ extension_publication_file (accessed on 20 October 2016).

5. Airaksinen, S.; Heinonen-Tanski, H.; Heiskanen, M.-L. Quality of different bedding materials and their influence on the compostability of horse manure. J. Equine Vet. Sci. 2001, 21, 125-130. [CrossRef]

6. Korries, O.C. Untersuchung Pferdehaltender Betriebe in Niedersachsen: Bewertung unter dem Aspekt der Tiergerechtheit, bei Trennung in Verschiedene Nutzungsgruppen und Beachtung Haltungsbedingter Schäden. Ph.D. Thesis, School of Veterinary Medicine Hannover, Hannover, Germany, 2003.

7. Lundgren, J.; Pettersson, E. Combustion of horse manure for heat production. Bioresour. Technol. 2009, 100, 3121-3126. [CrossRef] [PubMed]

8. Swinker, A.M.; Tanner, M.K.; Johnson, D.E.; Benner, L. Composting characteristics of three bedding materials. J. Equine Vet. Sci. 1998, 18, 462-466. [CrossRef]

9. Kusch, S.; Oechsner, H.; Jungbluth, T. Biogas production with horse dung in solid-phase digestion systems. Bioresour. Technol. 2008, 99, 1280-1292. [CrossRef] [PubMed]

10. Böske, J.; Wirth, B.; Garlipp, F.; Mumme, J.; van den Weghe, H. Anaerobic digestion of horse dung mixed with different bedding materials in an upflow solid-state (UASS) reactor at mesophilic conditions. Bioresour. Technol. 2014, 158, 111-118. [CrossRef] [PubMed]

11. Cui, Z.; Shi, J.; Li, Y. Solid-state anaerobic digestion of spent wheat straw from horse stall. Bioresour. Technol. 2011, 102, 9432-9437. [CrossRef] [PubMed]

12. Li, W. High-Solid Anaerobic Codigestion of Horse Manure and Grass in Batch and Semi-continuous Systems. Energy Fuels 2016, 30, 6419-6424. [CrossRef]

13. Mönch-Tegeder, M.; Lemmer, A.; Oechsner, H.; Jungbluth, T. Investigation of the methane potential of horse manure. Agric. Eng. Int. 2013, 15, 161-172.

14. Mönch-Tegeder, M.; Lemmer, A.; Oechsner, H. Enhancement of methane production with horse manure supplement and pretreatment in a full-scale biogas process. Energy 2014, 73, 523-530. [CrossRef]

15. Obernberger, I.; Brunner, T.; Barnthaler, G. Chemical properties of solid biofuels—Significance and impact. Biomass Bioenergy 2006, 30, 973-982. [CrossRef]

16. Wachendorf, M.; Richter, F.; Fricke, T.; Graß, R.; Neff, R. Utilization of semi-natural grassland through integrated generation of solid fuel and biogas from biomass. I. Effects of hydrothermal conditioning and mechanical dehydration on mass flows of organic and mineral plant compounds, and nutrient balances. Grass Forage Sci. 2009, 64, 132-143. [CrossRef]

17. Hensgen, F.; Richter, F.; Wachendorf, M. Integrated generation of solid fuel and biogas from green cut material from landscape conservation and private households. Bioresour. Technol. 2011, 102, 10441-10450. [CrossRef] [PubMed]

18. Zerr, W. Versuchsanlage zur energetischen Beurteilung von Substraten und Kofermentaten für Biogasanlagen. Umweltwissenschaften und Schadstoff-Forschung 2006, 18, 219-227. [CrossRef]

19. Verein Deutscher Ingenieure. VDI 4630 Vergärung Organischer Stoffe: Substratcharakterisierung, Probenahme, Stoffdatenerhebung, Gärversuche; Beuth: Berlin, Germany, 2006.

20. Friedl, A.; Padouvas, E.; Rotter, H.; Varmuza, K. Prediction of heating values of biomass fuel from elemental composition. Anal. Chim. Acta 2005, 544, 191-198. [CrossRef]

21. Van Soest, P.J.; Wine, R.H. Use of detergents in the analysis of fibrous feeds. IV. Determination of plant cell-wall constituents. J. Assoc. Off. Anal. Chem. 1967, 50, 50-55. 
22. R Core Team. R: A Language and Environment; R Foundation for Statistical Computing: Vienna, Austria, 2013.

23. Field, A.P.; Miles, J.; Field, Z. Discovering Statistics Using R; Sage: London, UK; Thousand Oaks, CA, USA, 2012.

24. Giraudoux, P. Pgirmess \& Pgirbric, Miscellaneous Functions for Data Handling and Analysis in Ecology. 2014. Available online: http:/ / giraudoux.pagesperso-orange.fr/ (accessed on 30 October 2014).

25. Hensgen, F.; Bühle, L.; Donnison, I.; Frasier, M.; Vale, J.; Corton, J.; Heinsoo, K.; Melts, I.; Wachendorf, M. Mineral concentrations in solid fuels from European semi-natural grasslands after hydrothermal conditioning and subsequent mechanical dehydration. Bioresour. Technol. 2012, 332-342. [CrossRef] [PubMed]

26. Aho, M.; Paakkinen, K.; Taipale, R. Quality of deposits during grate combustion of corn stover and wood chip blends. Fuel 2013, 104, 476-487. [CrossRef]

27. Jenkins, B.M.; Baxter, L.L.; Miles, T.R., Jr.; Miles, T.R. Combustion properties of biomass. Fuel Process. Technol. 1998, 54, 17-46. [CrossRef]

28. Deutsches Institut für Normung e. V. Feste Biobrennstoffe-Brennstoffspezifikationen und-Klassen-Teil 6: Nicht-Holzartige Pellets für Nichtindustrielle Verwendung; Deutsche Fassung; Beuth: Berlin, 2012.

29. Piepenschneider, M.; de Moor, S.; Hensgen, F.; Meers, E.; Wachendorf, M. Element concentrations in urban grass cuttings from roadside verges in the face of energy recovery. Environ. Sci. Pollut. Res. 2015, 22, 7808-7820. [CrossRef] [PubMed]

30. Bühle, L.; Hensgen, F.; Donnison, I.; Heinsoo, K.; Wachendorf, M. Life cycle assessment of the integrated generation of solid fuel and biogas from biomass (IFBB) in comparison to different energy recovery, animal-based and non-refining management systems. Bioresour. Technol. 2012, 111, 230-239. [CrossRef] [PubMed]

31. Erste Allgemeine Verwaltungsvorschrift zum Bundes-Immissionsschutzgesetz; TA Luft: Berlin, Germany, 2002.

32. Kolar, L.; Marsalek, M.; Frelich, J.; Kuzel, S.; Smetana, P.; Zednikova, J.; Svecova, M. Changes in methane release from organic matter passing through the digestive tract of horses. Czech J. Anim. Sci. 2009, 54, 112-120.

33. Hensgen, F.; Bühle, L.; Donnison, I.; Heinsoo, K.; Wachendorf, M. Energetic conversion of European semi-natural grassland silages through the integrated generation of solid fuel and biogas from biomass: Energy yields and the fate of organic compounds. Bioresour. Technol. 2014, 154, 192-200. [CrossRef] [PubMed]

34. Yenigün, O.; Demirel, B. Ammonia inhibition in anaerobic digestion: A review. Process Biochem. 2013, 48, 901-911. [CrossRef]

35. Pöschl, M.; Ward, S.; Owende, P. Evaluation of energy efficiency of various biogas production and utilization pathways. Appl. Energy 2010, 87, 3305-3321. [CrossRef] 